\title{
PENGARUH INFUSA DAUN SAMBILOTO (Andrographis paniculata Nees) TERHADAP PERTUMBUHAN BAKTERI Shigella dysenteriae SECARA IN VITRO
}

\author{
Fitri Nadifah, Siti Fatimah, Indah Yuliana Barekola Lamablawa \\ STIKes Guna Bangsa Yogyakarta
}

\begin{abstract}
Background: Bacteria Shigella dysenteriae is pathogenic bacterium which cause diarrheal diseases that enter into inside the body through intestine. Shigella dysenteriae constitute one of the gram negative bacterium which causes inflammation on intestinal, pain abdominal, tenesmus, and a bowel movements which accompanied with blood and mucus. Bad impact irational use of synthethic drugs and antibiotics can cause organ damage and germs resistance. Utilization of herbs as traditional medicine evolving rapidly and alternatively used by most. Traditional medicine has relatively low of side effect and affordable prices. Sambiloto (Andrographis paniculata Nees) is a plant which is ordinary used as a traditional medicine that can easily found around Indonesian islands. Sambiloto constitute one of the medicinal plants which is allegedly has the antibacterial effect because its chemical content of flavonoid saponins and tannin.

The objective of this study is to know the influence of sambiloto (Andrographis paniculata Nees) leaves infuse against the growth of Shigella dysenteriae bacteria.

Method: This is an experimental research using diffusion method. Statistical test who used namely analysis of variant one road (One Way anova). Analysis data were done descriptively and statistically and presented with of tables or graphs.

Results: There is influence of sambiloto leaf infusa (Andrographis paniculata Nees) against the growth of Shigella dysenteriae bacteria in vitro with a mean diameter zone of radical on concentrations the smallest $20 \%$ is $12 \mathrm{~mm}$ and the greatest concentration $100 \%$ is $24.3 \mathrm{~mm}$.

Conclusion: Infuse leaf has a strong and positive influence in inhibit the growth of bacteria Shigella dysenteriae bacterium.
\end{abstract}

Key words: Antibacterials, Andrographis paniculata Nees, Shigella dysenteriae.

\section{PENDAHULUAN}

Shigella dysenteriae adalah bakteri intestinal patogen yang telah lama dikenal sebagai agen penyebab penyakit disentri basiller. Shigella merupakan bakteri gram negatif, berbentuk bacillus, non-motil, tidak membentuk spora, dan merupakan bakteri anaerob fakultatif yang tidak berkapsul. Bakteri ini menyebabkan disentri yang berat dan invasif. Manifestasi klinis yang ditimbulkannya dapat berupa diare sedang sampai banyak, yang disertai panas dan mual, dengan sifat watery (diare dengan komposisi feses didominan cairan/air) ataupun diare berdarah. Kadang manifestasinya mungkin tidak menunjukkan gejala (McKane and Kandel, 1986).

Selama ini antibiotik direkomendasikan untuk mengobati "bloody diarrhea" (diare disertai darah) untuk memperpendek masa sakit, menurunkan morbiditas, dan mengurangi durasi perubahan siklus hidupnya (McKane and Kandel, 1986). Pemakaian obat-obatan antibakteri yang kurang rasional menyebabkan timbulnya resistensi sejumlah bakteri dan efek samping yang merugikan bagi penderita sehingga perlu dilakukan suatu penelitian untuk mencari obat antibakteri alternatif yang efektif murah dan mudah didapat dengan memanfaatkan tanaman obat yang diduga efektif menghambat pertumbuhan atau membunuh bakteri penyebab penyakit (Supriadi, 2001).

Salah satu tanaman obat yang banyak dimanfaatkan adalah daun sambiloto (Andrographis paniculata) yang banyak dijumpai di hampir seluruh kepulauan Nusantara. Daun sambiloto mengandung saponin, flavonoid, alkaloid, fenol dan tanin. Kandungan kimia lain yang terdapat pada daun dan batang adalah laktone, panikulin, kalmegin dan hablur kuning yang memiliki rasa pahit. Secara tradisional sambiloto telah dipergunakan untuk mengobati gigitan ular atau serangga, demam, disentri, rematik, tuberculosis, infeksi pencernaan, dan lain-lain. Sambiloto juga dimanfaatkan untuk antimikroba/antibakteri, anti sesak napas dan untuk memperbaiki fungsi hati (Yusron, 2005). Daun sambiloto mempunyai beberapa kandungan kimia yang sudah diketahui dengan jelas antara lain tanin, flavonoid, saponin, andrografolida, deoksiandrografilia, neo-andrografilia, panikolina, apigenin dan 
beberapa mineral (kalium, kalsium, natrium) asam kresik dan damar yang terdapat pada daunnya (Mangan, 2003). Penelitian ini bertujuan untuk mengetahui pengaruh berbagai konsentrasi infusa daun sambiloto (Andrographis paniculata Nees) terhadap pertumbuhan bakteri Shigella dysenteriae secara in vitro.

\section{METODE PENELITIAN}

Objek penelitian ini adalah daun sambiloto yang diperoleh dari daerah Godean, Yogyakarta. Sampel daun sambiloto diolah menjadi infusa dengan cara: simplisia (daun sambiloto yang sudah dikeringkan) ditimbang sebanyak 10 gram. Daun sambiloto dimasukan ke dalam erlenmeyer yang berisi aquadest steril $10 \mathrm{ml}$. Daun sambiloto tersebut dipanaskan di atas penangas air selama 15 menit terhitung mulai dari suhu mencapai $90^{\circ} \mathrm{C}$ sambil sesekali diaduk. Infusa daun sambiloto disaring dengan menggunakan corong yang di atasnya sudah diberi kertas saring steril dan didapatkan infusa daun sambiloto $100 \%$. Infusa daun sambiloto yang sudah diperoleh dimasukkan dalam sumuran media Muller Hinton $(\mathrm{MH})$ yang telah ditanam bakteri Shigella dysenteriae dan diinkubasi dalam inkubator selama 24 jam. Diamteter zona hambat (bening) di sekitar sumuran pada media $\mathrm{MH}$ dihitung menggunakan mistar.

\section{HASIL DAN PEMBAHASAN}

Setelah proses inkubasi, terlihat adanya zona hambat yang berwarna bening di sekitar sumuran. Hal ini menunjukkan bahwa infusa daun sambiloto mempunyai kemampuan dalam menghambat pertumbuhan bakteri Shigella dysenteriae (Gambar 1).
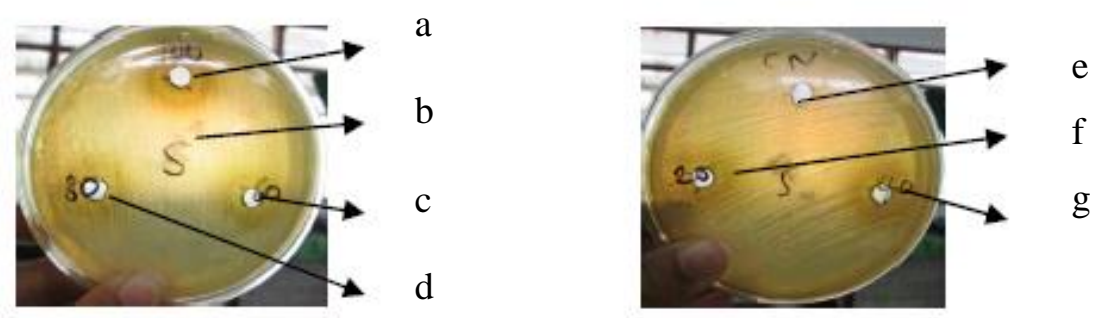

Gambar 1. Zona hambat infusa daun sambiloto terhadap pertumbuhan bakteri Shigella dysenteriae pada media $\mathrm{MH}$. Zona hambat yang digunakan sebagai parameter adalah zona di sekitar sumuran yang tampak bening tidak ada pertumbuhan bakteri.

Hasil pengamatan pertumbuhan bakteri pada media $\mathrm{MH}$ yang telah diamati kemudian di masukan ke dalam tabel hasil untuk mengetahui besarnya pengaruh daya hambat sambiloto terhadap bakteri Shigella dysenteriae dapat dilihat pada Tabel 1 dibawah ini:

Tabel 1. Hasil pengukuran diameter zona hambat infusa daun sambiloto

\begin{tabular}{|l|l|l|l|l|l|l|}
\hline \multirow{2}{*}{ Ulangan } & \multicolumn{6}{l|}{ Diameter zona hambat $(\mathrm{mm})$} \\
\cline { 2 - 7 } & Kontrol - & $20 \%$ & $40 \%$ & $60 \%$ & $80 \%$ & $100 \%$ \\
\hline 1 & 0 & 11 & 15 & 17 & 20 & 26 \\
\hline 2 & 0 & 13 & 16 & 21 & 22 & 25 \\
\hline 3 & 0 & 12 & 17 & 19 & 21 & 22 \\
\hline Rata-rata & 0 & 12 & 16 & 19 & 21 & 24.3 \\
\hline
\end{tabular}

Dari Tabel 1 diatas dapat diketahui bahwa infusa daun sambiloto memiliki daya hambat terhadap bakteri Shigella dysenteriae. Diameter zona hambat terkecil adalah pada Konsentrasi infusa 20\% dengan rerata diameter zona $12 \mathrm{~mm}$ dan diameter terbesar adalah pada konsentrasi $100 \%$ sebesar 24,3 $\mathrm{mm}$. Hal ini menunjukkan bahwa pada konsentraasi terendah (20\%) sudah mampu menghambat pertumbuhan bakteri dan semakin tinggi konsentrasi infusa daun sambiloto akan menghasilkan diameter zona hambat yang semakin tinggi atau daya hambatnya semakin kuat.

Berdasarkan hasil penelitian yang telah diolah dengan Anova satu jalan didapatkan nilai $F$ hitung sebesar 29,456 dan $F$ tabel sebesar 3,478 yang berarti $F$ hitung lebih besar dari $F$ tabel $(29,456>3,478)$ dan nilai signifikansinya lebih kecil dari 0,05 . Hal ini hipotesis yang diajukan, yaitu berbagai konsentrasi infusa daun sambiloto mempunyai pengaruh yang signifikan dalam menghambat pertumbuhan bakteri Shigella dysenteriae dapat diterima. Hasil uji regregasi linier juga 
menunjukan bahwa nilai $R$ Square (r2) diperoleh angka sebesar 0,911 yang berarti besarnya pengaruh daya hambat antibakteri Shigella dysenteriae adalah sebesar 91,1\% dan yang lain sisanya sebesar 8,9\% yang dapat dipengaruhi oleh faktor lain.

Peristiwa

penghambatan

pertumbuhan bakteri pada media ditunjukkan dengan daerah bening. Pada daerah tersebut tidak ada pertumbuhan bakteri. Peristiwa penghambatan terhadap pertumbuhan bakteri Shigella dysenteriae terutama karena adanya flavonoid, tanin dan saponin. Senyawa flavonoid dan tanin merupakan turunan senyawa fenol. Fenol bekerja dengan mengubah molekul protein dan asam nukleat melalui denaturasi protein bakteri dan merusak sel membran. Membran sel bakteri bersifat permeabel selektif berfungsi transpor aktif dan mengontrol komposisi internal sel. Jika fungsi integritas membran sel rusak maka makromolekul dan ion keluar dari sel, zat-zat yang seharusnya tidak masuk sel akan masuk menyebabkan metabolisme sel terganggu kemudian sel rusak dan berakibat pada kematian sel (Jawetz, 2005).

Senyawa Flavonoid adalah suatu kelompok senyawa fenol yang terbesar yang ditemukan dalam senyawa fenol larut dalam air, sangat mudah larut dalam eter dan dalam minyak menguap, agak sukar larut dalam mineral, sehingga pengolahan dan pembuatan air infusa daun sambiloto tidak perlu terlalu lama (15 menit) karena dikhawatirkan kandungan kimia (turunan fenol) dalam daun sambiloto menguap.

Melihat dari uraian di atas menunjukkan hipotesis yang diajukan dapat diterima bahwa ada pengaruh yang signifikan antara air infusa daun sambiloto terhadap Shigella dysenteriae secara invitro. Infusa daun sambiloto terbukti mampu menghambat pertumbuhan Shigella dysenteriae sehingga infusa daun sambiloto bersifat bakterisida dan diharapkan dapat dijadikan obat alternatif terhadap penyakit diare yang disebabkan oleh bakteri Shigella dysenteriae. Peristiwa penghambatan pertumbuhan bakteri pada media ditunjukkan dengan daerah bening. Pada daerah tersebut tidak ada pertumbuhan bakteri. Peristiwa penghambatan terhadap pertumbuhan bakteri Shigella dysenteriae terutama karena adanya flavonoid, tanin dan saponin. Senyawa flavonoid dan tanin merupakan turunan senyawa fenol. Fenol bekerja dengan mengubah molekul protein dan asam nukleat melalui denaturasi protein bakteri dan merusak sel membran. Membran sel bakteri bersifat permeabel selektif berfungsi transpor aktif dan mengontrol komposisi internal sel. Jika fungsi integritas membran sel rusak maka makromolekul dan ion keluar dari sel, zat-zat yang seharusnya tidak masuk sel akan masuk menyebabkan metabolisme sel terganggu kemudian sel rusak dan berakibat pada kematian sel (Jawetz, 2005).

Senyawa Flavonoid adalah suatu kelompok senyawa fenol yang terbesar yang ditemukan dalam senyawa fenol larut dalam air, sangat mudah larut dalam eter dan dalam minyak menguap, agak sukar larut dalam mineral, sehingga pengolahan dan pembuatan air infusa daun sambiloto tidak perlu terlalu lama (15 menit) karena dikhawatirkan kandungan kimia (turunan fenol) dalam daun sambiloto menguap.

\section{KESIMPULAN DAN SARAN}

Berdasarkan hasil penelitian yang telah dilakukan maka dapat disimpulkan bahwa infusa daun sambiloto (Andrographis paniculata Nees) berpengaruh dalam menghambat pertumbuhan Shigella dysenteriae secara in vitro. Besarnya pengaruh berbagai konsentrasi infusa daun sambiloto dalam menghambat pertumbuhan bakteri Shigella dysenteriae adalah sebesar $91,1 \%$. Konsentrasi terbesar infusa, yaitu $100 \%$ mampu menghambat pertumbuhan bakteri dengan rata-rata diameter zona hambat $24,3 \mathrm{~mm}$. Kami menyarankan agar dilakukan penelitian lanjut tentang penggunaan ekstrak daun sambiloto untuk pengobatan penyakit disentri yang disebabkan bakteri Shigella dysenteriae. Infusa daun dapat digunakan sebagai langkah awal dalam penelitian menggunakan ekstrak sehingga ke depannya dapat dihasilkan sediaan yang lebih praktis diaplikasikan oleh masyarakat.

\section{DAFTAR PUSTAKA}

Jawetz, E., J. L. Melnick and E. A. Adelberg.1986. Mikrobiologi untuk Profesi Kesehatan. Edisi 16. EGC, Jakarta.

Mangan. M. 2003. Budidaya dan Pemanfaatan Tanaman Obat. Jakarta. Penebar Swadaya.

McKane, L and J. Kandel. 1986. Microbiology: Essentials and Applications. Singapore. McGraw-Hill.

Supriadi. 2001. Tumbuhan Obat Indonesia Penggunaan dan Khasiatnya. Jakarta. Pustaka Populer Obor.

Yusron, M. 2005. Budidaya Tanaman Sambiloto. Badan Penelitian dan Pengembangan Pertanian, Balai Penelitian Tanaman Obat dan Aromatika. Yogyakarta. 